\title{
Management control, culture and ethnicity in a Chinese Indonesian company
}

\author{
Sujoko Efferin ${ }^{a}$, Trevor Hopper ${ }^{\text {b,c,* }}$ \\ ${ }^{a}$ Universitas Surabaya, Surabaya, Indonesia \\ ${ }^{\mathrm{b}}$ Manchester Business School, University of Manchester, Manchester M13 9PL, UK \\ c Stockholm School of Economics, Sweden and Victoria University, Wellington, New Zealand
}

\begin{abstract}
This study explores socio-cultural aspects of management control in a Chinese Indonesian manufacturing company. Ethnographic data collection methods were combined with grounded theory data analysis to explore how cultures, ethnic differences, history, politics, and commercial considerations shaped management controls. A combination of emic and etic methods were used to generate grounded comparisons with nomethetic research on culture and control in a cultural contingency tradition.

Chinese Indonesians own most Indonesian private domestic capital despite being an ethnic minority (3-4\% of population) and having suffered extensive discrimination. The case links the Chinese businessmen's values to socialisation during childhood and then examines how their interaction with the Javanese culture of pribumi employees, ethnic tensions between employers and employees, and organisational and economic factors affected management control. Consistent with previous cultural contingency research the Chinese owners' preferences resided with controlling behaviour through personnel and behavioural controls, low budget participation, centralisation, subjective rather than objective controls, and tentatively, few rewards tied to results and the use of group rewards. Whether Chinese managers exhibited longer term orientations concerning planning and rewards could not be ascertained. However, ethnic tensions and commercial considerations mitigated the owners' ability to control according to cultural preferences. Based upon these findings reflections on past research and suggestions for further developments are made with respect to methods, methodology, and incorporating a broader range of theories and issues, especially ethnicity, politics, and history.
\end{abstract} (C) 2006 Elsevier Ltd. All rights reserved.

\footnotetext{
${ }^{*}$ Corresponding author. Address: Division of Accounting and Finance, Manchester Business School, University of Manchester, Crawford House, Booth Street East, Manchester M13 9PL, UK. Tel.: +44 161275 4014; fax: +44 1612754023.

E-mail addresses: s_efferin@ubaya.ac.id (S. Efferin), Trevor.Hopper@mbs.ac.uk (T. Hopper).
}

\section{Introduction}

There has been considerable interest in whether national cultures produce different control systems (see Bhimani, 1999; Harrison \& McKinnon, 1999). 